\title{
The Perception of Soft Skills and Their Training at Hotel Front - Office in Connection to CoVid-19 Pandemics
}

\author{
Stepan Chalupa, Karel Chadt \\ Institute of Hospitality Management in Prague, Svidnicka 506, Prague, Czech Republic
}

\begin{abstract}
This paper deals with soft skills training in the hospitality industry during the pandemic of Covid 19. Based on the semi-structured interviews with hotel and front office managers, the main topics of communication with clients and their issues were identified, and the insufficiencies in employee approach towards these situations. The findings show that the employees are not prepared for critical situations and need proper soft skills training. This paper proposes virtual reality as a platform for real situation training, including feedback and in-training evaluation.
\end{abstract}

Keywords - Soft skills training, in-field training, soft skills development, hospitality.

\section{Introduction}

The current hospitality industry is being influenced by worldwide Covid-19 pandemic and derived restrictions that changed the consumer's behaviour entirely not only in tourism in general but especially in gastronomy and hospitality industries.

This article focuses on identifying the shift in employee - client communication in front-office with emphasis on the soft skills and their training.

DOI: $10.18421 /$ TEM102-05

https://doi.org/10.18421/TEM102-05

Corresponding author: Stepan Chalupa, Institute of Hospitality Management in Prague, Svidnicka 506, Prague, Czech Republic.

Email: chalupa@vsh.cz

Received: 11 February 2021.

Revised: 18 March 2021.

Accepted: 22 March 2021.

Published: 27 May 2021.

(c) BY-NC-ND (C) 2021 Stepan Chalupa \& Karel Chadt; published by UIKTEN. This work is licensed under the Creative Commons Attribution-NonCommercial-NoDerivs 4.0 License.

The article is published with Open Access at www.temjournal.com
The soft skills are essential competencies within the hospitality industry, and the education providers should shift from intensive training of hard competencies to the soft ones [1].

Bharwani \& Jauhari [2] created an innovative construct of Hospitality Intelligence which consist of the Emotional Intelligence, Cultural Intelligence and Hospitality Experiential Intelligence for hiring and training front line employees in the hospitality industry, where the delivery of the high quality of services and maximisation of customer satisfaction is the key to success. Within Emotional Intelligence, several constructs and dimensions can be found and classified within the Interpersonal and Intrapersonal Competencies groups.

As proposed by Tas [3] or Walls et al. [4], the core dimensions are empathy and effective communication. Empathy represents the ability to listen and understand the customer's feelings and interpret the unspoken. The empathy is as well connected to the appreciation and acceptance of different point of view [2].

On the other hand, effective communication is highly connected to the clarity of the information and building and maintaining two-way communication with clients.

Lenehan [5] widens the domain of interpersonal dimensions (skills) by adding the concepts of influencing skills, which can be described as an assertive approach to the persuasion of hotel guest for further consumption and reduction of resistance to a new experience through reasonable arguments, and feedback-seeking, which is connected to the ability to gather and evaluate the honest guest feedback.

Another identified dimensions are flexibility and conflict solution skills [6]. Flexibility represents the ability to deal uncertainties within customer behaviour due to the variability of needs and wants. These uncertainties may cause several crises and conflicts, where the front line employees have to stay calm, non-defensive and create and propose the creative solution for the aroused situation. 
Customer needs' anticipation is closely connected with the previously mentioned concepts of flexibility and conflict solution skills. On the other, the frontline employees should anticipate the customers' need and wants and predict their behaviour to minimise communication errors and misunderstandings [7].

Juahari [8] added the ability to work in a team and follow a common goal and shared vision and mission.

Excluding from the interpersonal skills, the soft skills consist of intrapersonal skills. Lashley [9] stress the importance of emotional resilience (the ability to resist the provocations and adversity), optimism and commitment to deliver high-quality services and hospitality. Goleman [10] describes another set of intrapersonal concepts, the selfawareness and self-management.

All skills, concepts and dimensions of Hospitality Intelligence mentioned before can be perceived as soft skills, and we should stress their importance in the hospitality industry.

The authors used semi-structured interviews with Front-Office and hotel managers, to identify the main reasons for interaction with hotel quest and the proposed processing of various queries. The managers lately evaluated their employees' readiness for crisis-communication and information delivery and description of soft-skills training planes.

This study presents the current perception of soft skills training in the hospitality industry and proposes the solution within strengthening the position of practical training and application of tools of distant education (in this case Virtual Reality).

\section{Literature Review}

As mentioned in the previous section of this paper, soft skills play a crucial role within the hospitality industry. They directly influence the guest experience, guest satisfaction, and overall guest experience and the entrepreneur's point of view of his employees' work performance. To stick with this paper's main topic, the following text consists of improving the level of soft skill in the hospitality industry based on the current research in this domain.

Ibrahim, Boerhannoeddin \& Bakare [11] stated that the work performance and ability to maintain the high level of work performance have made training and development programmes the essential part of business operations. On-the-job training is different from formal education and learning methodologies, where the adults shared different characteristics to young student and pupils. Maria \& Elena [12] described these characteristics of adults learners as follows.
- The participation is closely connected to predefined goal, expectations and intentions;

- Learners are having a certain level of knowledge and experience and a fixed perception of various concepts;

- Developed a style of learning;

- Time and activity boundaries connected to real life;

- New obstacles within the learning experience.

The trainers should reflect the characteristics when creating the training and development programmes. To plan the training programme, the managers should identify the need for training and connect them with the appropriate training method. In the current research, we can find several training methodologies.

Ibrahim, Boerhannoeddin \& Bakare [11] propose "time-spaced learning" as a useful tool to increase work performance by developing soft skills. The learning spaces can be described as any places where training and learning occur (real and virtual classrooms or chat rooms). This methodology adds the learning brakes to the training process, leading to applying gained knowledge in the work-life before further learning milestones.

Another approach can be strongly connected to practical education and its crucial part, the internships, which follow the methodology of "problem-based learning". Based on the reports from New Zealand hospitality students' internships, "problem-based learning" can lead to the development of communication skills, teamwork and Professionalism, and personal development [12].

The internships can be as well perceived as a bridge between standardised education and professional placements and work. Based on the detailed discussion with Filipino hospitality interns, it can be stated that the internships can shape and improve the expectations connected to work experience [13].

Dhyani, Dimri \& Gairola [14] measured hotel employees' work performance and job satisfaction and employee retention. The highly trained employees with access to further education and development are more closely connected to their employers. This means that training can be used to retain precious employees.

Kim \& Joeng [15] are mentioning two primary modern methodologies for education. The method of "learning by doing "where the practical experience and theoretical knowledge fixation during practical training and active training, where the trainer should activate the learners to deliver the high level of selected competencies. 
Singh \& Jaykumar [16] identified the gap between the required soft skill level and gained a soft skill level of hospitality entry-level positions. This study's conclusion is not only in developing a closer connection between the industry professionals and enterprises and the education providers but also in applying practical training during the first days in the company based on previously mentioned methods.

Kiryakova-Dineva, Kyurova \& Chankova [17] are focusing on the sustainability issues connected to soft skills and their training while mentioning the lack of soft skills development by educators who prioritise the hard skills. The authors state that sustainable development can be achieved only by combining hard and soft skills in connection with individual employees' career path.

\section{Data and Method}

To identify the changes in perception of skills development, the authors used semi-structured questioning of hotel front-office, H.R. and operations managers hotels and accommodation facilities. The total sample consists of 59 managers who evaluated the soft skills mentioned in the Introduction section of this study on the Likert Scale and their perception of a shift in "client-front-office employee" communication. They were as well ask to state their strategy within the soft skills training.

As national measures significantly influenced the whole industry, the authors used purposive sampling, focusing on the still operating hotels and other accommodation facilities.

To identify the shift in "client- front-office employee" communication, the small group of 5 hospitality professional with a direct connection to front-office operations were asked to create to list of situations of this interaction as well as the times for soft skills training, development and verification during the phases of the employee contract.

The following paragraph describes the results and key findings of the research. To evaluate the importance of the soft skills, and their interconnectivity, the authors, used not only the descriptive statistics but as well the Pearson's Correlation coefficient $\boldsymbol{\rho}$, that was calculated using the following formula,

$$
\rho(\mathrm{X}, \mathrm{Y})=(\operatorname{cov}(\mathrm{X}, \mathrm{Y})) /(\sigma \mathrm{X} \sigma \mathrm{Y})
$$

where $\rho$ is the value of correlation coefficient, $X$ and $\mathrm{Y}$ are the random variables, cov $(\mathrm{X}, \mathrm{Y})$ their covariance and $\sigma \mathrm{X}$ and $\sigma \mathrm{Y}$ their standard deviations of the variables $\mathrm{X}$ and $\mathrm{Y}$.

\section{Results}

Within the results, it is essential to focus on the perception of identified soft skills based on their importance, listed below in Table 1.

Table 1. Evaluation of the importance of soft skills

\begin{tabular}{|l|c|c|}
\hline & Mean & $\begin{array}{c}\text { Standard } \\
\text { Deviation }\end{array}$ \\
\hline Empathy & 6.627 & .488 \\
Effective Communication & 6.525 & .858 \\
Influencing Skills & 6.034 & .870 \\
Attentiveness & 5.797 & .979 \\
Observation Skills & 6.017 & .731 \\
Willingness to Serve & 6.610 & .720 \\
Flexibility & 6.729 & .691 \\
Problem Solving & 6.763 & .429 \\
Team Member & 6.644 & .483 \\
Emotional Resilience & 6.508 & .504 \\
Optimism & 6.017 & .731 \\
Creativity & 6.017 & .731 \\
Professionalism & 6.627 & .488 \\
\hline
\end{tabular}

Based on Table 1, it is clear that the highest-rated skills are Problem Solving, Flexibility, Team Play, Professionalism, Empathy, Effective Communication an Emotional Resilience. However, it is essential to look for the connection between these variables to find a consensus on evaluating the variables. Using the previously mentioned correlation coefficient, the strongest positive connection was identified for the following pairs of variables.

- Problem Solving and Effective Communication $\boldsymbol{\rho}=1$

- Team Play and Influencing Skills $-\boldsymbol{\rho}=\mathbf{0 , 8 9 1}$

- Team Play and Effective Communication $\boldsymbol{\rho}=\mathbf{0 , 7 5 0}$

- Team Play and Problem Solving - $\boldsymbol{\rho}=\mathbf{0 , 7 5 0}$

- Problem-Solving and Influencing Skills $\rho=0,668$

- Influencing Skills and Effective Communication $-\rho=0,668$

When focusing on the negative correlation between variables, we have identified only the significant negative connection between Professionalism and Empathy $\boldsymbol{\rho}=\mathbf{- 0 , 5 9 5}$.

We can assume that the front office employees need to work in the team and solve the problem, influence the customers and communicate effectively. These concepts are directly linked to main problems being solved before the pandemics (mainly the stay problems connected to noise, cleanliness and unfriendliness of the front office employees) and during the pandemics (reservation cancellations and reimbursement and information delivery). 


\section{Training Strategy}

The authors also asked the managers to describe their current strategy connected to front office employees' soft skills during various employment stages. The managers were asked if they evaluate and test the soft skills during the hiring process. Half of them stated that they evaluate the candidates based on their soft skills but do not use any comprehensive strategy to test them practically. They mainly focus on the following aspects.

- Appearance during the interview;

- Feedback from previous employers and recommendation letters;

- Passed certification during previous employments;

- Highest achieved education.

These main instruments can only partially or indirectly display soft skills, and we cannot afford them as the approach to soft skills testing.

\section{Soft Skills Development Before the First Shift}

The authors also asked the managers about the infield training before the first shift during the boarding process. The half of the respondents stated that during the onboarding, the employees are going through the induction course and for the first weak they are followed by their mentors who observe their performance and give them valuable feedback. Half of these respondents also allowed new employees to pass the external training focusing on the Professionalism and other soft skills provided by the Czech Association of Hotels and Restaurants.

\section{Soft Skills Development During the Employment}

More than $75 \%$ of the respondents stated that they train their employees by providing direct feedback, self-evaluation sessions, and external professional training. They as well stimulate the employees to share their experience with other team members. The employees are given the comprehensive program for the predefined period when they should pass these training, which helps them improve their planning skills and follow the personalised development strategy.

On the other hand, less than $40 \%$ of the respondents stated that they are planning new training after the pandemics. The decrease in participation is mainly caused by the lack of finance and their reallocation to other departments. We have asked these managers to state their perception of this training reduction and $15 \%$ of them shared their worries connected to lack of skilled professional on the front office which is the vital part of the hotel and guest experience. They also stated that they have already lost a few great employees who shifted to different, more profitable industries.

\section{Soft Skills Development During Pandemics of Covid-19}

The last area was directly connected to the training of soft skill during the pandemic. None of the respondents stated that they trained their employees to deal better with the issues and request form the clients and less only $12 \%$ of the respondents realised the training to share at least the necessary info about the hygienic measures at the way these should be communicated with clients.

\section{Discussion}

The findings of authors' research bring wider consequences for hospitality recovery strategies created by researcher and hospitality professionals. Wong et al. [18] analysed the impact of Covid 19 pandemics on the employee's stress which was mainly caused by traditional work-related stressors and unstable and more demanded hotel work stressors and unethical labour practices stressors. Combining these stressors leads to the loss of highly skilled professionals and decreased performance due to the negative perception of the activities caused by lack of experience and training.

Putting these findings into the context of recommended strategies for hospitality industry recovery focusing on the use of modern technologies to increase the safety and security of the hotel clients [19], improving the hygiene standards of hotel and restaurant operations [20], distribution diversification and market orientation [21]. We should state that the hoteliers have to hire and work with hospitality professional and enthusiast even to start working on the recovery strategies and plans.

The results presented in previous sections show the need for continuous learning and knowledge sharing to secure key employees and improve their efficiency [22] and indirectly, the accommodation facility's performance. This approach is suitable for building sustainable H.R. strategy, which is in the scope of several authors [23] and improving other managerial levels like decision-making [24].

\section{Conclusion}

The hospitality industry faces the lower demand for the services caused by measures on a national and international level and should be as well prepared efflux of qualified labour. The hotel managers have to prepare hiring and training and development strategies that would help them prosecute personalised recovery plans. As there is limited personal and practically oriented training, the hoteliers should apply modern technologies to simulate the in-field training.

One of the technologies is Virtual Reality, where the programmers can simulate the front office environment and then let the users "play" the procreated scenarios. This training should maintain high employee motivation and satisfaction, which isthe critical element of high-quality services. 


\section{Acknowledgements}

This article was created as the results of the project TL04000153 "Aplikace nástrojů virtuální reality do tréninku komunikačnich dovedností pracovníkủ hotelů za účelem zmírňováni obav a rizik spojených s šiřením onemocněni COVID-19" funded by Technology Agency of the Czech Republic.

\section{References}

[1]. Sisson, L. G., \& Adams, A. R. (2013). Essential hospitality management competencies: The importance of soft skills. Journal of Hospitality \& Tourism Education, 25(3), 131-145.

[2]. Bharwani, S., \& Jauhari, V. (2013). An exploratory study of competencies required to co-create memorable customer experiences in the hospitality industry. International Journal of Contemporary Hospitality Management, 25(6), 823-843.

[3]. Tas, R. F. (1988). Teaching future managers. Cornell Hotel and Restaurant Administration Quarterly, 29(2), 41-43.

[4]. Walls, A., Okumus, F., Wang, Y., \& Kwun, D. J. W. (2011). Understanding the consumer experience: An exploratory study of luxury hotels. Journal of Hospitality Marketing \& Management, 20(2), 166197.

[5]. Lenehan, T. (2000). A study of management practices and competences within effective organisations in the Irish tourism industry. Service Industries Journal, 20(3), 19-42.

[6]. Kay, C., \& Russette, J. (2000). Hospitalitymanagement competencies: Identifying managers' essential skills. Cornell hotel and restaurant administration quarterly, 41(2), 52-63.

[7]. Erdly, M., \& Kesterson-Townes, L. (2003). " Experience rules": a scenario for the hospitality and leisure industry circa 2010 envisions transformation. Strategy and Leadership, 31(3), 1218.

[8]. Jauhari, V. (2006). Competencies for a career in the hospitality industry: an Indian perspective. International Journal of Contemporary Hospitality Management, 18(2), 123-134.

[9]. Lashley, C. (2008). "Marketing Hospitality and Tourism Experiences.". In Handbook of Hospitality Marketing Management Edited by: Oh, H. 331. Oxford: Butterworth Heinemann.

[10]. Goleman, D. (1998). What makes a leader?. Harvard Business Review, 76(6), 93-102.

[11]. Ibrahim, R., Boerhannoeddin, A., \& Bakare, K. K. (2017). The Effect of Soft Skills and Training Methodology on Employee Performance. European Journal of Training and Development, 41(4), 388406.
[12]. Losekoot, E., Lasten, E., Lawson, A., \& Chen, B. (2018). The development of soft skills during internships: The hospitality student's voice. Research in Hospitality Management, 8(2), 155-159.

[13]. De Guzman, A., Bayot, J. M., Javier, N., Liamzon, R. R., \& Moralejo, M. A. R. (2020). Understanding Filipino hospitality interns' expectations and frustrations. Anatolia, 31(3), 479-493.

[14]. Dhyani, A., Dimri, R., \& Gairola, V. (2020). Soft Skill-Based Training Model for Employee Retention. International Journal of Strategic Decision Sciences (IJSDS), 11(4), 37-48.

[15]. Kim, H. J., \& Jeong, M. (2018). Research on hospitality and tourism education: Now and future. Tourism Management Perspectives, 25, 119122.

[16]. Anjana, S., \& Prashnati, J. (2019). On the road to consensus: key soft skills required for youth employment in the service sector. Worldwide Hospitality and Tourism Themes, 11(1), 10-24.

[17]. Kiryakova-Dineva, T., Kyurova, V., \& Chankova, Y. (2019). Soft skills for sustainable development in tourism: the Bulgarian experience. European Journal of Sustainable Development, 8(2), 57-57.

[18]. Wong, A. K. F., Kim, S. S., Kim, J., \& Han, H. (2021). How the COVID-19 pandemic affected hotel Employee stress: Employee perceptions of occupational stressors and their consequences. International Journal of Hospitality Management, 93, 102798.

[19]. Pillai, S. G., Haldorai, K., Seo, W. S., \& Kim, W. G. (2021). COVID-19 and hospitality 5.0: Redefining hospitality operations. International Journal of Hospitality Management, 94, 102869.

[20]. Herédia-Colaço, V., \& Rodrigues, H. (2021). Hosting in turbulent times: Hoteliers' perceptions and strategies to recover from the Covid-19 pandemic. International Journal of Hospitality Management, 94, 102835.

[21]. Rodríguez-Antón, J. M., \& Alonso-Almeida, M. D. M. (2020). COVID-19 Impacts and Recovery Strategies: The Case of the Hospitality Industry in Spain. Sustainability, 12(20), 8599. https://doi.org/10.3390/su12208599

[22]. Urbancová, H., \& Vrabcová, P. (2020). Age management as a human resources management strategy with a focus on the primary sector of the Czech Republic. Agricultural Economics, 66(6), 251259. doi:10.17221/11/2020-agricecon

[23]. Urbancová, H., \& Vrabcová, P. (2020). Factors Influencing the Setting of Educational Processes in the Context of Age Management and CSR. Economics \& Sociology, 13(3), 218-229.

[24]. Petricek, M. (2017). Managerial Utility Function and Its Impact on Decision-Making In The Company. In Slavikova, P. (Ed) Proceedings of Knowledge for Market use 2017: People in Economics - Decisions, Behavior and Normative Models. 